\title{
LEGAL GAP: PERTENTANGAN HUKUM MASYARAKAT DAN HUKUM NEGARA
}

\author{
Moh. Syaeful Bahar \\ UIN Sunan Ampel Surabaya | Jl. Ahmad Yani II7 Surabaya | \\ bosbahar@yahoo.com
}

\begin{abstract}
This article highlights the controversy of revised act of corruption commission (UU KPK) and of the Book of Criminal Law (KUHP) which had heated up. By using legal gap theory, this writing uncovers the legal gap between the contents of revised KUHP and living laws. Consequently, people in the grassroots level seem more enthusiastic about the issue, for example, the fines because livestock entering other people yards than weakening KPK issues that drive a wave of demonstrations at the level of well-educated people. Many studies in the sphere of sociology of law that have conducted gave much attentions to the living law or norm in the mods of society. However there is not much of them which gave attention to the legal gap phenomena, it is the incompatibility between living law and formal one. Whereas, such an approach tend to be considered late if it we aim to put the sociology of law as one discipline of social science which is useful in strengthening the law enforcement. In the hilt of the matter, there is an issue of the legal gap which should have been expressed from the beginning, mainly as to the compatibility between formal and informal law when legislation was going on. By utilizing literature study, the research found that; firstly, the resistance against revised KUHP is the logical consequence of legal gap phenomena that has potential legal conflict. Secondly, there are four major manners could be done to resolve the gap; repression, counseling, reformation and restorative justice.
\end{abstract}

Keywords: Legal Gap, Living Law, Restorative.

Abstrak: Artikel ini menyoroti kontroversi rancangan revisi undangundang KPK dan KUHP yang sempat memanas. Dengan menggunakan teori kesenjangan hukum (legal gap), tulisan ini mengungkap bahwa terdapat kesenjangan hukum antara sebagian isi revisi KUHP dengan hukum yang hidup di tengah masyarakat. Akibatnya, masyarakat akar 
rumput tampaknya lebih antusias menyoroti isu misalnya denda ayam masuk pekarangan orang lain ketimbang isu pelemahan KPK yang menggerakkan gelombang demonstrasi di level masyarakat terdidik. Beberapa kajian di bidang sosiologi hukum yang telah dilakukan banyak memberikan perhatian terhadap hukum atau norma yang hidup di tengah-tengah masyarakat. Namun belum banyak di antaranya yang memberikan perhatian terhadap fenomena legal gap, yaitu kesenjangan living law dengan hukum formal. Padahal, pendekatan semacam ini cenderung 'terlambat' jika ditujukan untuk meletakkan sosiologi hukum sebagai disiplin keilmuan yang lebih berdaya guna terhadap penegakan hukum. Di hulu persoalan ini, terdapat isu kejanjangan hukum (legal gap) yang semestinya disuarakan sejak awal, terutama meyangkut kesesuaian antara hukum formal dan informal pada saat proses legislasi sedang berlangsung. Dengan memanfaatkan kajian literatur, penelitian ini menemukan bahwa; pertama, penolakan terhadap KHUP merupakan konsekuensi dari fenomena legal gap yang berpotensi menjadi konflik hukum. Kedua, ada empat cara yang bisa dilakukan untuk mengatasi kesenjangan tersebut; represi, penyuluhan, reformasi, dan keadilan restorative.

Kata Kunci: Legal Gap, Living Law, Restoratif.

\section{Pendahuluan}

Belum lama ini, masyarakat Indonesia dihebohkan dengan kontroversi lahirnya beberapa undang-undang yang dibahas dan segera menunggu pengesahan dari DPR RI. Di antara undangundang dimaksud adalah RUU KPK, KUHP, Ketenagakerjaan, Sumber Daya Air dan seterusnya. ${ }^{1}$

Undang-undang revisi KPK tentu menjadi isu yang paling utama di antara semua racangan undang-undang yang dibahas tersebut. Dampak dari RUU ini adalah pecahnya kerusuhan setelah gelombang demo mahasiswa semakin hari semakin besar menyuarakan dibatalkannya revisi undang-undang yang disinyalir melemahkan komisi anti rasuah tersebut.

Menariknya, atensi masyarakat semakin besar mengiringi perdebatan pengesahan rancangan beberapa undang-undang di

\footnotetext{
I https://news.detik.com/berita/d-4720722/daftar-ruu-disahkan-ditangguhkan-dan-yang-masihjadi-tuntutan-mahasiswa (diakses 4-2-2020 jam 19.00)
} 
akhir masa jabatan DPR periode 2014-2019 tersebut. Termasuk rancangan undang-undang KUHP yang baru, menggantikan KUHP lama. Bahkan, beberapa rancangan peraturan dari RUU KUHP menjadi topik pembahasan utama yang menggelinding hingga ke level akar rumput.

Ketimbang isu Dewan Pengawas dalam RUU KPK, perhatian masyarakat di akar rumput tampaknya lebih banyak diramainkan dengan diskursus mengenai ancaman pidana bagi pemilik hewan ternak yang peliharaannya memasuki pekarangan tetangga, misalnya. Sebagaimana dalam draft yang sampai ke publik, pasal 279 menjelaskan bahwa:

“Setiap orang yang membiarkan ternaknya berjalan di kebun, tanah perumputan, tanah yang ditaburi benih atau penanaman, atau tanah yang disiapkan untuk ditaburi benih atau ditanami dipidana dengan pidana denda paling banyak kategori II".

Kategori II yang dimaksud ini adalah denda sebesar sepuluh juta rupiah. Sontak, terutama bagi masyarakat pedesaan, isu ini langsung ramai. Tidak hanya di dalam perbincangan luring, media daring bahkan dipenuhi oleh beragam meme kocak yang menyindir dimasukkannya pasal ini.

Meski RKUHP ini kemudian gagal disahkan, berbeda dengan RUU KPK yang tetap disahkan, namun terdapat satu frame yang dapat kita tangkap dari perbicangan kedua rancangan undangundang ini. Isu korupsi bagi sebagian orang masih cenderung elitis karena berputar di lingkaran sekelompok kecil elit ${ }^{2-}$ meski faktanya daya rusaknya begitu besar- sehingga penolakannya lebih terpusat pada mobilisasi suara di level kalangan terdidik dan menengah ke atas.

Berbeda dengan RUU KUHP di mana beberapa pasal menyentuh langsung kepentingan masyarakat akar rumput. Akibatnya meski tidak teraktualisasikan dalam gelombang

${ }^{2}$ George Economakis, Yorgos Rizopoulos \& Dimitrios Sergakis, Patterns of Corruption, Journal of Economics and Business Vol. XIII - 2010, No 2, II-31. 
demonstrasi penolakan seperti undang-undang KPK, namun pasal KUHP lebih banyak dibicarakan oleh masyarakat aras bawah.

Kerangka penyikapan publik terhadap rancangan undangundang baik KPK maupun KHUP ini tentu bukan semata karena tipologi kepentingan keduanya yang berbeda. Apalagi sekadar diferensiasi elitis maupun populis tidaknya isu kedua undangundang tersebut. Dalam perspektif sosiologi hukum, penulis menangkap ada aspek kesenjangan hukum (legal gap) yang berbeda di antara keduanya.

Legal gap terjadi ketika terjadi kesenjangan atau pertentangan antara hukum positif formal dengan hukum informal yang hidup di tengah-tengah masyarakat (living law). ${ }^{3}$ Dalam bentuk lebih lanjut, legal gap ini diyakini dapat memunculkan konflik hukum (legal conflict).

Dalam kajian sosiologi hukum, kesenjangan hukum ini seringkali luput dari perhatian. Hal ini disebabkan oleh perhatian sementara para pegiat kajian sosiologi hukum yang cenderung memusatkan kajian kepada bagaimana penegakan hukum tertentu dinilai menciderai rasa keadilan yang hidup di tengah-tengah masyarakat. ${ }^{4}$ Beberapa kasus yang secara yuridis formal benar, dalam sudut pandang ini menjadi kehilangan 'rasa' saat mendistorsi apa yang hidup di tengah-tengah masyarakat.

Pada tahap selanjutnya, keputusan hakim menjadi aspek yang juga mengundang atensi para pemerhati kajian sosiologi hukum. Para hakim dikritisi karena cenderung kaku dalam menerapkan hukum yang tertulis (law in books), sementara abai untuk menggali hukum yang ada di tengah-tengah masyarakat (law in society). ${ }^{5}$

\footnotetext{
${ }^{3}$ Lihat Soetandyo Wignjosoebroto, Hukum dalam Masyarakat, ed.II. (Yogyakarta: Graha IImu, 2013)

${ }^{4}$ Lihat Umar Sholehudin, Hukum dan Keadilan Sosial : Kajian Sosiologi Hukum tentang Kasus Pencurian Satu Buah Semangka yang Dilakukan Dua Orang Miskin di Kelurahan Ngampel, Kecamatan Mojokerto, Kediri, (Tesis Unair, 20I I). Lihat juga Ibnu Artadi, "Hukum: antara Nilainilai Kepastian, kemanfaatan, dan Keadilan", Jurnal Hukum dan Dinamika Masyarakat, (Oktober 2006), 67-80.

${ }^{5}$ Lihat, misalnya Ery Setyanegara, "Kebebasan Hakim Memutus Perkara dalam Konteks Pancasila: Ditinjau dari Keadilan Substantif", Jurnal Hukum dan Pembangunan, tahun ke-44 No.4, (OktoberDesember 2013), 460-495. Bandingkan Muhammad Azil Masykur, "Potret Buram Positivisme
} 
Banyak penelitian di bidang sosiologi hukum memiliki nuansa semacam ini. Beberapa penelitian tersebut hampir bermuara kepada satu sentrum yang sama, yaitu keprihatinan terhadap rendahnya rekognisi terhadap living law.

Basis penelitian semacam ini sayangnya cenderung 'terlambat' jika ditujukan untuk meletakkan sosiologi hukum sebagai disiplin keilmuan yang berdaya guna terhadap penegakan hukum. Bagaimanapun juga fenomena yang disoroti beberapa penelitian terdahulu berada pada sisi hilir dari persoalan yang sebenarnya.

Di hulu persoalan ini, terdapat isu kejanjangan hukum (legal gap) yang semestinya disuarakan sejak awal, terutama meyangkut kesesuaian antara hukum formal dan informal pada saat proses legislasi masih berlangsung (ongoing process). Karena itulah, berbeda dengan sebelumnya, tulisan ini mengambil legal gap sebagai fokus kajian. ${ }^{6}$

Karena konsep legal gap berkaitan erat dengan living law, maka konsep Eugen Ehrlich ini tentu tetap mendapat porsi pembahasan untuk memberikan landasan pijak terhadap fokus utama tulisan ini. Legal gap menjadi penting disuarakan sebagai langkah preventif untuk memastikan bahwa hukum yang dibuat oleh negara mampu mengakomodir nilai dan norma masyarakat.

\section{Hukum yang Hidup}

Saat paradigma hukum positivistik mendalilkan bahwa law is society ${ }^{7}$, sosiologi hukum sebaliknya meyakini bahwa law is not always society. Acapkali apa yang dianggap sebagai hukum oleh negara, tidak lebih bermakna bagi masyarakat ketimbang nilai dan

\footnotetext{
Hukum: Sebuah Telaah terhadap Kasus-kasus Kecil yang Menciderai Rasa Keadilan Masyarakat", Jurnal Humani, vol. 6, No. I (2016), 4I-57.

${ }^{6}$ Penelitian Dodik Harnadi terkait dengan resistensi sebagian masyarakat terhadap undang-undang perlindungan anak dalam hubungannya dengan penerapan sanksi mendidik oleh para guru terhadap murid, memberikan atensi terhadap legal gap. Sayangnya, fokus utama penelitian tersebut tetap memberikan porsi besar terhadap living law serta model resistensi yang muncul, ketimbang aspek kesenjangan hukum yang hanya diletakkan sebagai pelengkap. Lihat Dodik Harnadi, Living Law dan Mekanisme Resistensi atas Undang-undang Perlindungan Anak di Kabupaten Bondowoso, tesis magister Sosiologi Unair, 2016

${ }^{7}$ Soetandyo Wignjosoebroto, Hukum dalam Masyarakat, ed.II. (Yogyakarta : Graha IImu, 20I3), 6
}

\section{\begin{tabular}{l|l}
58 & al-Daulah \\
Vol. I0. no. I. April 2020
\end{tabular}}


norma sebagai instrument mekanisme kontrol sosial yang lahir dari serta dipatuhi oleh mereka.

Nilai dan norma yang inferior dalam paradigm positivistik, justru menjadi sentrum dalam studi sosiologi hukum. Karl Von Savigny menyebutnya sebagai volksrecht ${ }^{8}$, Hoebel menyebutnya law-ways ${ }^{9}$ Sumner folkways ${ }^{10}$, sementara Eugen Ehrlich melahirkan istilah yang paling popular, living law atau das lebend Recht. ${ }^{11}$

Ehrlich menjadi salah satu yang cukup masyhur dikenal karena kontribusinya terhadap studi sosiologi hukum dengan mengajak para sarjana hukum untuk tidak sebatas melihat hukum dari apa yang tertulis, melainkan apa yang faktual berkembang di masyarakat. Ungkapan Ehrlich yang banyak disitat -dan pada kata pengantar dipromosikan sebagai inti dari keseluruhan isi bukunyaadalah:

"At the present as well as at any other time, the center of gravity of legal development lies not in legislation, nor in juristic science, nor in judicial decision, but in society itself 12

(Saat ini dan juga di waktu lain, pusat gravitasi pembangunan hukum bermuara bukan dalam proses legislasi, ilmu pengetahuan hukum, dan keputusan pengadilan, tetapi di dalam masyarakat itu sendiri)

Pendekatan hukum positivistik dikritik karena sering dinilai memiliki kesenjangan dengan kebudayaan. Padahal, kebudayaan dalam pengertian khusus nilai dan norma ${ }^{13}$ - adalah produk genuine

\footnotetext{
${ }^{8}$ Menurut Savigny, hukum apapun lahir-dan seharusnya demikian- dari masyarakat (volksrecht), termasuk hukum positif. Lihat Mauricio García-Villegas, the Powers of Law: A Comparative Analysis of Sociopolitical Legal Studies (Cammbridge: Cambridge University Press, 20 I 8), 42

${ }^{9}$ Adamson Hoebel, Law-Ways of the Primitive Eskimos, Journal of Criminal Law and Criminology, Vol. 3 I, Isu 6 Maret- April (1940- 194I), 663-683

10 William Graham Sumner, Folkways: A Study of Sociological Importance of Usages, Manners, Customs, Mores, and Morals (Ginn \& Company, 1911)

" Lihat Eugen Ehrlich, Fundamental Principles of the Sociology of Law (London: Routledge Taylor and Francis Group, 2017)

${ }^{12}$ Pengantar penulis dalam Eugen Ehrlich, Fundamental Principles of the Sociology of Law (London: Routledge Taylor and Francis Group)

13 Lihat George Ritzer, Teori Sosiologi : Dari Sosiologi Klasik sampai Perkembangan Terakhir Postmodern (Yogyakarta: Pustaka Pelajar, 20 I2)
} 
yang lahir dari nurani masyarakat (volks-geist) ${ }^{14}$. Bisa jadi, fenomena inilah yang menimbulkan ketidaknyamanan saat sebagian orang berurusan dengan hukum, terutama jika itu merugikannya secara fisik maupun meteriil.

Salah satu adagium hukum menyebut, lex dura sed tamen scripta; hukum itu kejam dan demikianlah adanya. Ungkapan ini seolah menarik satu pengandaian bahwa hukum beroperasi dalam ruang yang berjarak dengan perasaan manusia. Akibatnya, saat hukum ditegakkan, sering kali muncul teriakan, bahwa ia telah menentang rasa keadilan dalam masyarakat.

Berbeda dengan hukum positivistik, sosiologi hukum justru memusatkan atensinya kepada kebermaknaan hukum secara sosial (the social significance of law ). Artinya, hukum semestinya dipahami sebagai bagian integral masyarakat, bukan terpisah apalagi bertentangan dengan mereka. Hukum itu bermakna serta dihayati oleh mereka sehingga secara sukarela dipatuhi sebagai mekanisme kontrol sosial sehari-hari. ${ }^{15}$

Selanjutnya apa yang Ehrlich maksudkan dengan living law? apakah sama dengan nilai atau norma yang berkembang di tengah-tengah mereka?. Merujuk kepada pernyataan Ehrlich, dengan living law dia memaksudkan sebuah hukum yang mendominasi kehidupan orang meskipun tidak sampai dikodifikasikan sebagai hukum formal oleh negara. ${ }^{16}$

Dengan demikian, living law memiliki jangkauan luas mencakup system nilai yang paling berhubungan dengan kehidupan banyak orang. Living law mendahului -meski tidak selalu- sekaligus melampaui limitasi hukum negara. Di sini kita bisa mengerti kenapa tidak semua hukum yang dibuat oleh negara mencerminkan masyarakat secara penuh (law is not always society).

Living law tidak selalu melampaui hukum formal modern, karena bisa jadi hukum yang hidup ini timbul dari penerimaan sepenuhnya masyarakat terhadap hukum formal tersebut. Karena

\footnotetext{
${ }^{14}$ Roger Cotterrell, Sosiologi Hukum: the Sociology of Law (Bandung: Nusamedia, 20 I4), 30

15 Soetandyo Wignjosoebroto, Hukum dalam Masyarakat, 6

${ }^{16}$ Ehrlich, Fundamental Principles of the Sociology of Law.., 493
} 
itulah, Ehrlich secara tegas mengatakan bahwa salah satu sumber hukum yang hidup (living law) adalah dokumen hukum formal modern, dalam konteks Indonesia adalah undang-undang.

"The source of our knowledge of this law is, first the modern legal document, secondly, direct observation of life, of commerce, of customs and usages and of all associations, not only those that the law has recognized but also those that it has overlooked and passed by, indeed even those that it has disapproved". ${ }^{17}$

Merujuk kepada pernyataan ini, untuk mengetahui living law, dapat mengamati beberapa hal berikut; pertama, dokumen hukum formal negara. Kedua, mengamati langsung kehidupan masyarakat dengan segenap cara berniaga, adat kebiasaan, tata cara kehidupan serta beragam bentuk model hubungan sosial.

\section{Hukum Rakyat-Hukum Positif: Relasi Pertentangan}

Tidak semua living law dikonversi menjadi hukum positif, pun demikian juga tidak semua formula hukum positif mengambil akarnya dalam hukum yang hidup. Saat hukum positif yang baru lahir menawarkan satu gagasan normatif yang terbilang baru, sementara nilai lama yang ada belum mengakomodasinya, maka situasi ini relatif tidak menimbulkan persoalan, bahkan hal ini menjadi perlu untuk menjawab kompleksitas permasalahan hukum di tengah-tengah masyarakat.

Secara teoritis, kondisi di atas menggambarkan apa yang disebut gap in law (ketimpangan dalam hukum). Ketimpangan dalam hukum terjadi ketika nilai atau norma yang ada belum mampu menjawab persoalan baru yang muncul di tengah warga. Demikian terjadi karena persoalan yang muncul adalah kejadian baru ataupun hukum belum menyentuhnya sama sekali.

Gap in law ini terutama digunakan untuk menggambarkan persoalan hukum yang terjadi di kawasan Amerika Selatan. Terdapat kasus-kasus hukum di mana hukum yang ada tidak mampu menjawabnya.

17 Ibid 
Istilah gap in law ini semakna dengan terminology lacuna of law. Ketimpangan dalam hukum-baik dalam pengertian gap in law maupun lacuna of law- adalah atau krisis regulasi tertentu untuk menjawab kasus konkret yang dinilai belum terakomodir oleh regulasi tersebut.

Persoalan baru muncul ketika hukum positif produk dari legislasi ataupun kodifikasi hukum oleh negara melahirkan norma baru yang bersinggungan dengan norma lama yang hidup di tengah masyarakat atau ketika hukum positif bertolak belakang dengan hukum rakyat, living law. Ketika pertentangan ini terjadi, muncullah apa yang disebut sebagai kesenjangan hukum atau legal gap.

Istilah legal gap ini relatif baru dibandingkan istilag gap in law. Kesenjangan hukum adalah silang selisih antara hukum yang tertulis dengan hukum yang secara aktual dihayati oleh rakyat. ${ }^{18}$

Kesenjangan hukum adalah persoalan faktual dan aktual, namun juga sekaligus klasik. Kesenjangan hukum muncul seiring dengan lahirnya paradaban bangsa dan negara yang menyeragamkan hukum hanya sebatas apa yang disahkan oleh badan khusus dalam hierarki negara yang berwenang membukukan hukum. Akibatnya, hukum-hukum informal yang sudah lebih dulu dihayati harus diletakkan subordinat bahkan tereliminir oleh hukum negara yang terbilang baru.

Secara aktual, fenomena ini terus berlangsung seiring dengan aktivitas legislasi negara yang mendasarkan perumusan formula hukum tertentu pada sumber luar yang tidak selalu seirama dengan sumber lokal. Katakanlah hukum yang bersumber dari nilai-nilai global yang sejatinya merepresentasikan nilai-nilai dari negara globalizer di barat. ${ }^{19}$

Beberapa penolakan yang terjadi di Indonesia sehubungan dengan beberapa draft rancangan undang-undang baru belum lama ini mencerminkan fenomena legal gap atau kesenjangan hukum.

\footnotetext{
${ }^{18}$ Sotandyo Wignjosoebroto, Hukum dalam Masyarakat, 50

19 Baca Jeffrey T Jackson, The Globalizers: Development Worlers in Action (Baltimore: John Hopkins University Press, 2005)
} 
Sebagai ilustrasi, ancaman hukuman bagi pemilik hewan peliharaan yang memasuki halaman tetangga jelas bertentangan dengan hukum kebiasaan yang berkembang di tengah masyarakat.

Bagi masyarakat perkotaan (urban society) yang sudah tersofistikasi, tentu rancangan aturan ini tidak begitu menimbulkan persoalan berarti. Tetapi bagi masyarakat pedesaan (rural society) sebagai habitat tumbuh kembangnya nilai-nilai asali masyarakat Indonesia, rancangan aturan di atas jelas bersinggungan dengan kebiasaan warga.

Secara klasikal, legal gap ini adalah fenomena yang pada abad ke-19 menjadi alasan Karl Von Savigny menyuarakan gagasannya mengenai hukum rakyat yang kemudian popular sebagai living law. Hukum ini adalah hukum alami yang mengekspresikan secara kuat apa yang disebutnya sebagai semangat rakyat (volksgeizt).

Gagasan ini lahir seiring dengan menguatnya keinginan negara Jerman saat itu untuk melakukan kodifikasi hukum serta meletakkannya sebagai satu-satunya ekspresi hukum masyarakat yang telah mengalami legalisasi negara. Bagi Savigny, tindakan Jerman ini menjadi malapataka bagi kebuayaan itu sendiri.

Hukum yang dikodifikasi negara memiliki model operasi yang berbeda dengan hukum rakyat dari sisi kealamiahannya mengawal proses evolusi budaya. Hukum positif memaksakan evolusi budaya berjalan secara mekanik, berbeda dengan hukum rakyat yang beroperasi secara alami. ${ }^{20}$

Fenomena legal gap tentu tidak bisa diabaikan, terutama dalam proses konstruksi hukum negara. Salah satu dampak yang paling terlihat adalah resistensi dari masyarakat. Dalam kasus Indonesia, ini terlihat dari seringnya gerakan penolakan rakyat muncul mengiringi proses perumusan aturan baru yang dinilai bertentangan dengan nilai dan norma setempat.

Ada dua hal yang setidaknya bisa menjelaskan hal ini. Pertama, ada proses rekognisi kebudayaan yang diabaikan saat aturan baru yang berlawanan dibentuk oleh negara. Sebagai khazanah budaya,

${ }^{20}$ Cotterrell, Sosiologi Hukum..., 30 
masyarakat tertentu berharap bahwa negara memberikan pengakuan terhadap mekanisme budaya yang menjadi kekayaan mereka di pelbagai tempat.

Saat paradaban negara modern menegaskan superioritas hukum yang dibentuk negara terhadap hukum kebiasaan, persoalan sejatinya telah lahir. Bagi sebagian masyarakat, hukum informal yang bersumber dari kebiasaan setempat kadang dipandang lebih bermakna dan dihayati oleh mereka daripada hukum yang dibuat oleh negara. Alih-alih diakui (rekognisi), dalam rasionalisasi negara modern mereka justru harus- sebaliknyamengakui hukum negara sebagai satu-satunya hukum yang harus mereka patuhi.

Kedua, resistensi bisa semakin kencang saat aturan baru muncul justru bertentangan secara langsung dengan norma lokal. Terlebih saat pengabaian terhadapnya dianggap sebagai sikap merendahkan kebudayaan setempat. Ini menjadi persoalan serius yang semestinya dipertimbangkan sejak awal.

Dalam perkembangan lebih lanjut, saat aturan baru dibentuk, sementara masyarakat masih setia dengan hukum yang hidup di tengah mereka, maka terjadilah konflik hukum (legal conflict). ${ }^{21}$ Konflik hukum terjadi sebagai akibat dari legal gap yang tidak tertangani secara baik.

Dalam kasus Indonesia, konflik hukum muncul karena konstruksi hukum negara cenderung mengadopsi pendekatan transplantasi hukum ketimbang peminjaman hukum. ${ }^{22}$ Legal transplanting adalah proses di mana hukum negara mencangkok hukum yang bersumber dari tradisi negara berbeda.

Berbeda dengan transplantasi hukum yang cenderung dipaksakan, peminjaman hukum (legal borrowing) lebih adaptif. Peminjaman hukum selalu didasarkan atas penyesuaian hukum baru dengan situasi dan kondisi faktual.

Idealnya, penerapan hukum baru yang dikodifikasikan oleh negara, tidak menafikan kekhasan situasi kebudayaan setiap

\footnotetext{
${ }^{21}$ Soetandyo, Hukum dalam Masyarakat, 50

22 Untuk lebih lanjut Soetandyo, Hukum dalam Masyarakat, 64
} 
masyarakat. Negara dapat saja meletakkan hukum sebagai sarana untuk melakukan perubahan sosial, tetapi untuk menghindari resistensi yang kuat, ia harus tetap diselaraskan dengan situasi setempat.

\section{Mengelola Legal Gap di Indonesia}

Faktanya, ada banyak produk hukum negara yang lahir mengabaikan keselarasannya dengan kebudayaan lokal. Bisa jadi ini disebabkan oleh living law sebagai sebuah mekanisme kontrol sosial lokal kurang dapat diadaptasi seiring dengan tantangan perubahan yang semakin cepat. Terutama di era teknologi informasi yang menuntut inklusivitas serta penerimaan terhadap kebudayaan global sebagai atribut yang dibawa oleh globalisasi.

Jika hukum buatan pemerintah secara nyata bertentangan dengan living law, konflik hukum berpotensi muncul akibat resistensi yang dilakukan oleh masyarakat. Beberapa kasus sering kali muncul dari begitu kuatnya masyarakat memegang teguh adat istiadat tertentu, sementara hukum negara telah tegas mengatur larangan terhadapnya.

Akibatnya resistensi muncul dalam beragam bentuk, termasuk pengabaian - lebih tepatnya deviasi- terhadap hukum positif sebagai konsekuensi dari kengototan untuk tetap mempertahankan dan melaksanakan adat istiadat di mana hukum positif mengatur larangan terhadapnya. Saat resistensi semacam ini muncul, maka konflik hukum tidak terhindarkan.

Oleh karena itu, perlu dilakukan pendekatan untuk mencegah kesenjangan hukum (legal gap) berlanjut menjadi konflik hukum. Soetandyo menjelaskan tiga kebijakan yang bisa dilakukan untuk mencegah polarisasi yang semakin menguat antara hukum positif dengan hukum yang hidup di tengah-tengah masyarakat.

Tujuan dari tiga kebijakan ini tentu dalam rangka menanamkan nilai-nilai hukum positif sebagai norma baru yang harus diterima oleh warga. Dengan demikian, sikap dualisme penerimaan masyarakat terhadap kedua entitas hukum yang bersinggungan tersebut berakhir pada satu pengabaian terhadap 
yang satu (living law) sekaligus penerimaan terhadap yang lain (hukum positif).

Ketiga kebijakan yang dimaksud adalah pendayagunaan sanksi, penyuluhan hukum dan reformasi hukum. ${ }^{23}$ Pertama, pendayagunaan sanksi adalah pendekatan represif dengan memaksa warga untuk patuh terhadap satu-satunya hukum yang harus dipatuhi, yaitu hukum negara.

Setiap potensi pengabaian terhadap hukum negara harus didekati secara represif dengan memaksimalkan sanksi untuk memastikan bahwa rakyat patuh dan loyal hanya kepada hukum yang disusun negara. Hal ini sah dilakukan karena negara menjadi satu-satunya otoritas yang boleh melakukan pemaksaan terhadap rakyatnya, terutama dengan menjadikan hukum sebagai instrumen pemaksanya. ${ }^{24}$

Dalam konteks terjadinya kesenjangan hukum, rakyat dipaksa untuk mematuhi hukum positif meskipun bersinggungan dengan hukum yang hidup. Pada akhirnya, negara berharap rakyat, suka atau tidak, hanya mematuhi satu aturan yang sah yaitu hukum positif yang ditetapkan oleh negara.

Kedua, kesenjangan hukum dapat ditekan agar tidak meletus menjadi konflik hukum melalui penyuluhan. Jika kebijakan pertama bersifat represif, kebijakan kedua lebih edukatif. Rakyat diberikan pemahaman yang 'benar' bahwa apa yang dirumuskan sebagai hukum positif harus dipatuhi terlepas ia bersinggungan dengan hukum kebiasaan di tengah mereka.

Pada kondisi tertentu, pemaksaan dengan sanksi tidak selalu efektif, bahkan berpotensi memunculkan resistensi yang semakin besar. Pendekatan yang halus dengan menyentuh lebih dalam kesadaran masyarakat tentu bisa mencipatakan penerimaan yang alamiah dan substantif dari pada yang represi yang cenderung pragmatis.

\footnotetext{
${ }^{23}$ Soetandyo, Hukum dalam Masyarakat..., 54

${ }^{24}$ Hukum sendiri menurut Burton Leiser, memiliki kekuatan memaksa (law is coercive) karena ditujukan untuk menundukkan rakyat terhadap keingunan negara melalui ancaman sanksi yang diberikan. Lihat Burton Leiser, On Coercion dalam David Reidy \& Walter Riker, Coercion and State (Berlin: Springer, 2008), 31
} 
Kebijakan ketiga adalah reformasi hukum (legal reform), alternatif terakhir yang bisa dilakukan untuk mengatasi kesenjangan hukum. Pendekatan pertama dan kedua bisa jadi tidak membawa perubahan signifikan terhadap upaya menjadikan hukum positif diterima oleh masyarakat.

Dalam situasi tersebut, hukum positif yang baru bisa jadi memang kurang relevan, terlampau maju, atau tidak menyentuh kebutuhan masyarakat. Oleh sebab itu, pilihan untuk merevisi hukum baru ini bisa jadi adalah pilihan terbaik. Dengan demikian, konflik hukum bisa tercegah dengan sendirinya.

Dalam konteks Indonesia, reformasi hukum ini sebetulnya menjadi mekanisme yang paling sering dilakukan saat aturan baru dinilai tidak memenuhi rasa keadilan dalam masyarakat. Keberadaan Mahkamah Konstitusi adalah wujud akomodasi negara terhadap potensi penolakan rakyat terhadap hukum baru yang dilaksanakan melalui langkah pengujian, disebut judicial review atau legislative review. ${ }^{25}$ Melalui proses legislative review maupun judicial review, undang-undang yang baru dibuat bisa saja dibatalkan karena pelbagai alasan yang dapat dipertanggungjawabkan secara yuridis.

Selain ketiga kebijakan ini, sebetulnya ada satu kebijakan lain yang bisa dilakukan untuk mengatasi kesenjangan hukum agar tidak berubah menjadi konflik hukum. Kebijakan yang dimaksud adalah penerapan prinsip restorative justice atau keadilan restoratif dalam kasus-kasus tertentu di mana hukum yang dibentuk secara nyata dan serius menyinggung nilai keadilan yang hidup.

Keadilan restoratif adalah proses penyelesaian hukum yang secara aktif diselesaikan oleh para pihak yang secara langsung maupun tidak langsung berhubungan dengan persoalan hukum tertentu seperti pelaku, korban serta pihak-pihak terkait. Mereka bersama-sama mencari jalan penyelesaian tanpa harus

\footnotetext{
${ }^{25}$ Selain judicial reviewyang diajukan ke Mahkamah Konstitusi, dikenal juga legislative review melalui lembaga legislatif, Jimly Asshiddiqi, Konstitusi dan Konstitusionalisme (Konstitusi Press, 2005), 284
} 
menyertakan penyelesaian di meja peradilan (out of court settlement). ${ }^{26}$

Model ini mungkin tidak berpretensi mengubah atau membatalkan undang-undang baru yang mengalami kesenjangan dengan hukum rakyat. Namun, karena penyelesaian terhadap persoalan hukum yang timbul dari kesenjangan ini diselesaikan oleh masyarakat sendiri, maka ruang untuk tetap menerima dan mengakomodir hukum yang hidup semakin besar.

Dan terakhir, pendekatan hukum progresif dapat menjadi cara mengatasi kesenjangan hukum. Hukum progresif terutama sekali berkaitan dengan konstruksi berfikir para hakim untuk berani dan keluar dari kekangan tekstual undang-undang dengan melampauinya serta memberikan perhatian terhadap aspek-aspek lain seperti sosial budaya sebagai pijakan memutuskan perkara hukum. ${ }^{27}$

Hukum progresif berpijak di atas madhab fungsi ketimbang bentuk..$^{28}$ Hukum semestinya diabdikan untuk mesyarakat dan ia menjadi penentu bagaimana semestinya hukum telah memberinya kepuasan atau tidak. Hal ini berbeda dengan para ahli hukum murni yang semata melihat hukum dari kacamata bentuk kakunya sebagaimana sudah terfosilisasi menjadi goresan teks demi teks aturan.

Pendekatan hukum progresif ini mendorong para hakim untuk berani membuat keputusan yang lebih berpihak kepada rasa dan nilai keadilan saat bunyi-banyi hukum tekstual dirasakan sebaliknya. Dalam kultur common law, di mana hakim berwenang membuat hukum (judge made law) pendekatan ini tentu cukup mudah dilakukan.

Namun bagi hakim Indonesia, dengan kultur civil law di mana hakim hanya sebagai 'pembaca' dan pelaksana aturan hukum yang sudah tertulis, maka pendekatan progresif menjadi cukup sulit

\footnotetext{
${ }^{26}$ Baca Sir Anthony Mason, Restorative Justice: Courts and Civil Society in Heather Strang \& John Braithwaite (ed.), Restorative Justice: Philosophy to Practice (London: Routledge, 2016)

${ }^{27}$ Mengenai hukum progresif, baca Satjipto Raharjo, Membedah Hukum Progresif(Jakarta: Penerbit Buku Kompas, 2006)

${ }^{28}$ Satjipto Raharjo, Penegakan Hukum Progresif(Jakarta: Penerbit Buku Kompas, 20 I 0), 3
} 
diterapkan. Meski demikian, dalam konstruksi hukum Indonesia, hakim tidak perlu merasa 'bersalah' saat memutuskan perkara dengan mengacu kepada nilai yang hidup serta abai terhadap hukum positif.

Menyitat pasal 5 Undang-undang nomor 48 tahun 2009 tentang Kekuasaan Kehakiman, hakim berkewajiban menggali, mengikuti dan memahami nilai-nilai hukum dan rasa keadilan yang hidup di tengah-tengah masyarakat. Aturan ini cukup menjadi landasan yuridis bagi para hakim untuk bertindak lebih cerdas dengan membuat keputusan yang berpihak kepada hukum dan nilai yang hidup.

Keberanian sekeligus kecerdasan hakim untuk mulai memberikan ruang terhadap hukum dan nilai yang hidup, menjadi salah satu cara yang bisa dilakukan untuk mengatasi kesenjangan hukum bila mana hukum baru memang tidak memungkinkan diubah, sementara proses akseptabilitas warga masih lemah disebabkan pertentangannya dengan hukum yang hidup.

\section{Penutup}

Hukum tidak hanya aturan yang terkodifikasi menjadi hukum positif oleh negara. Hukum yang hidup di tengah-tengah masyarakat (living law) adalah hukum informal yang bisa jadi memiliki level penerimaan lebih kuat bagi sebagian orang.

Senyatanya, hukum positif harus selaras dengan hukum yang hidup sebagai ekspresi kebudayaan dan jati diri masyarakat. Keselarasan hukum yang hidup dengan hukum positif buatan negara dapat mencegah terjadinya konflik hukum pada era negara bangsa di mana hanya hukum negara yang diakui sebagai satusatunya hukum mengikat.

Sayangnya, tidak semua hukum positif bersumber dari hukum rakyat. Bahkan acapkali berlawanan dengannya. Pertentangan hukum rakyat dengan hukum positif negara memunculkan apa yang disebut legal gap. Legal gap adalah inkompatibilitas atau pertentangan hukum positif dengan hukum yang hidup, hukum tekstual dengan aktual. 
Ketika persinggungan hukum dibiarkan tidak tertangani, konflik hukum muncul. Oleh sebab itu, perlu dilakukan beberapa kebijakan dan pendekatan untuk mengatasi kesenjangan hukum serta mencegahnya berubah menjadi konflik hukum.

Beberapa cara bisa dilakukan, mulai dari pendekatan represif melalui pendayagunaan sanksi secara maksimal, hingga pendekatan edukatif melalui penyuluhan dengan memberikan pencerahan dan penyadaran. Saat kedua cara ini tidak efektif, maka alternative legal reform dengan merevisi atau membatalkan hukum positif yang baru bisa dilakukan.

Di samping ketiga cara di atas, dua pendekatan lain bisa diterapkan. Yaitu penyelesaian hukum dengan keadilan restiratif (restorative justice) dan pendekatan hukum progresif. Kedua cara ini, meski tidak meniadakan secara keseluruhan formula hukum positif yang bertentangan dengan hukum yang hidup, namun berguna untuk meminimalkan kesenjangan kedua hukum tersebut.

\section{Daftar Pustaka}

Artadi, Ibnu. "Hukum: antara Nilai-nilai Kepastian, kemanfaatan, dan Keadilan". Jurnal Hukum dan Dinamika Masyarakat, Oktober 2006, 67-80.

Asshiddiqi, Jimly. Konstitusi dan Konstitusionalisme. Jakarta: Konstitusi Press, 2005

Cotterrell, Roger. Sosiologi Hukum: the Sociology of Law. Bandung: Nusamedia, 2014.

Economakis, George. "Yorgos Rizopoulos \& Dimitrios Sergakis, Patterns of Corruption". Journal of Economics and Business Vol. XIII - 2010, No 2, 11-31.

Ehrlich, Eugen. Fundamental Principles of the Sociology of Law. London: Routledge Taylor and Francis Group, 2017.

Harnadi, Dodik. Living Law dan Mekanisme Resistensi atas Undangundang Perlindungan Anak di Kabupaten Bondowoso. Tesis-Unair, Surabaya, 2016. 
Hoebel, Adamson. "Law-Ways of the Primitive Eskimos". Journal of Criminal Law and Criminology, Vol. 31, Isu 6 Maret- April (19401941), 663-683

Jackson, Jeffrey T. The Globalizers: Development Worlers in Action. Baltimore: John Hopkins University Press, 2005.

Mason, Sir Anthony. Restorative Justice: Courts and Civil Society in Heather Strang \& John Braithwaite (ed.), Restorative Justice: Philosophy to Practice. London: Routledge, 2016.

Masykur, Muhammad Azil. "Potret Buram Positivisme Hukum: Sebuah Telaah terhadap Kasus-kasus Kecil yang Menciderai Rasa Keadilan Masyarakat". Jurnal Humani vol. 6, No. 1 (2016), 41-57

Raharjo, Satjipto. Membedah Hukum Progresif. Jakarta: Penerbit Buku Kompas, 2006.

Raharjo, Satjipto. Penegakan Hukum Progresif. Jakarta: Penerbit Buku Kompas, 2010.

Reidy, David \& Walter Riker. Coercion and State. Berlin: Springer, 2008.

Ritzer, George. Teori Sosiologi: Dari Sosiologi Klasik sampai Perkembangan Terakhir Postmodern. Yogyakarta: Pustaka Pelajar, 2012.

Setyanegara, Ery. "Kebebasan Hakim Memutus Perkara dalam Konteks Pancasila: Ditinjau dari Keadilan Substantif". Jurnal Hukum dan Pembangunan, tahun ke-44 No.4, Oktober-Desember 2013, 460-495.

Sholehudin, Umar. Hukum dan Keadilan Sosial : Kajian Sosiologi Hukum tentang Kasus Pencurian Satu Buah Semangka yang Dilakukan Dua Orang Miskin di Kelurahan Ngampel, Kecamatan Mojokerto, Kediri. Tesis--Unair, Surabaya, 2011.

Sumner, William Graham. Folkways: A Study of Sociological Importance of Usages, Manners, Customs, Mores, and Morals. Ginn \& Company, 1911.

Villegas, Mauricio García. The Powers of Law: A Comparative Analysis of Sociopolitical Legal Studies. Cambridge: Cambridge University Press, 2018. 
Moh. Syaeful Bahar

Wignjosoebroto, Soetandyo. Hukum dalam Masyarakat, ed.II. Yogyakarta: Graha Ilmu, 2013.

https://news.detik.com/berita/d-4720722/daftar-ruu-disahkanditangguhkan-dan-yang-masih-jadi-tuntutan-mahasiswa (diakses 4-2-2020 jam 19.00) 